of an industrial medical service, as is already the case at Slough and Harlow.

More concentration of accident cases in designated units will, in the absence of peripheral casualty services, result in these units being swamped with trivial conditions to an even greater extent than is the case with the casualty departments, and the day of treating these patients effectively, economically, and with the minimum loss of time-both at the time of the accident and during the all-important period of aftercare-will be further away than ever.-I am, etc.,

Birmingham 20 .

HaNs F. REICHENFELD.

REFERENCES

1 Accident Services of Great Britain and Ireland, Interim Report of Review Committee, 1961. B.M.A., London.

2 Ministry of Health, Central Health Services Council Standing Medical Advisory Committee, Accident and Emergency Services, 1962, Report of Subcommittee, H.M.S.O., London.

$s$ Fry, L., Lancet, 1960, 1, 163.

4 Crombie, D. L., J. Coll. gen. Practit., 1959, 2, 346

scEwan, E. D., and Gordon, Christie W., Midl. med. Rev., $1963,2,348$

- S.E. London G.P. Centre, Annual Report, 1962.

\section{Research in Mental Deficiency}

SIR,--I cannot agree with Dr. J. M. Crawford (May 11 , p. 1287) that the full-time workers in mental deficiency have contributed little to knowledge in this field. It is indeed extremely creditable that so much research was done in the past by workers who carried an enormous case-load and administrative burden. This was at a time when biological investigation into problems of mental defect was unfashionable and neglected by others.

Currently there are many active groups in the specialty, and it is largely due to the efforts of full-time workers in this field that the idea of an institute of mental deficiency is now being publicly mooted. It seems to me that, far from being in danger of erosion, the specialty is about to enter an era of exciting and fruitful work, which will be limited only by the financial resources, hitherto meagre in the extreme, applied to it. -I am, etc.,

$$
\begin{aligned}
& \text { South Ockendon Hospital, } \\
& \text { Romford, Essex. }
\end{aligned}
$$$$
\text { J. T. R. BAVIN. }
$$

SIR,-Much of the recent surge of interest in mental deficiency has been due to the work of doctors, psychologists, and biochemists employed full-time in mental deficiency hospitals; Dr. J. M. Crawford's worry (May 11, p. 1287) that their work may be whittled away is not likely to be realized if the hospitals are supported by adequate funds, staff, and laboratories-and in particular by an appreciation in other quarters of the work they already do.

Some large mental-deficiency hospitals are not as remote as Lord Taylor (April 27, p. 1107) thinks. Several have connexions with teaching hospitals, and medical students, coming to them and expecting a dreary day, find themselves in a bustling world of medical, psychological, neuropathological, cytogenic, biochemical, social, educational, and industrial research and practice. This, too, can come as a surprise to their teachers.-I am, etc.,

St. Lawrence's Hospital,
Caterham, Surrey.

JOHN GiBSON.

\section{Research in Mental Health}

SIR,-We were very interested in Lord Taylor's article (April 27, p. 1107). It shows what a vast amount of clinical and laboratory research is already being done, but it appears to us that most of the work is individual and insufficiently connected with work in other fields.

The M.R.C., which does splendid work already, has a research building under construction in this area, but research in mental health is only a fraction of its total medical-research programme. Moreover, to get the best from a mental-health research programme we consider it should be in close contact with all other branches of medical research. To realize this ideal we suggest that one of the London teaching hospitals should move into close contact with a group of closely associated mental institutions covering all branches of mental health. We consider that the site for such a medical school and mental hospital research centre exists in Epsom, Surrey.

This town is only 15 miles from the centre of London and is linked by a half-hourly rail service to three London terminals-namely, Waterloo, Victoria, and London Bridge. It already has an efficient and active central area laboratory, which is in direct communication with six adjacent mental hospitals providing approximately 8,000 general mental beds and 2,000 beds for subnormal patients, a public health service laboratory equipped for virus research, and a unit for incipient alcoholics. A neurosurgical unit is at present under consideration and two of the adjacent hospitals are scheduled for rebuilding by 1970 . In addition, the laboratory has direct contact with seven other mental hospitals in Surrey, and, finally, there is a local wellestablished general hospital in the town which could be the nucleus of a future general teaching hospital.

Several square miles of mental hospitals' farmlands, which are no longer required as work centres for patients, would provide ample space for a fine medical school, laboratories, and students' hostels, playing fields, and so on. What about a Surrey Medical School attached to London University, created by moving out one of the medical schools from overcrowded central London, where land is insufficient for further development?-We are, etc.,
Area Laboratory,
West Park Hospital Epsom, Surrey.
Myra K. Beattie. I. H. MACLEAN (retired).

\section{Immunological Pregnancy Tests}

SIR,-Since Wide and Gemzell's ${ }^{1}$ publication on the use of the inhibition of a haemagglutination reaction as a means of diagnosing pregnancy some commercial "test kits" have been produced for clinical use.

Results have been published comparing these immunological pregnancy tests with certain biological tests. Only a few hundred comparisons have so far been made, and the tests are usually done on urines from normal pregnant and non-pregnant women. In practice pregnancy diagnosis is not such a simple matter, and in this laboratory less than a third of the 24,000 to 25,000 tests done each year are for women with normal pregnancies. The majority of tests are for women with a threatened or missed abortion, ectopic pregnancy, retained placental tissue, hydatidiform mole, choriocarcinoma, and to establish the menopause. Tests are also done for men with testicular tumours.

When immunological tests are compared with those biological tests for pregnancy that are not very accurate, the speed and ease with which some immunological tests can be done makes them a very attractive substitute. However, the experience of this laboratory with 3,127 immunological tests done in parallel with the Hogben test on unselected material shows that their accuracy (based upon clinical confirmation of the test 
results) must be increased before they are substituted for a reliable biological test (see Table).

\begin{tabular}{|c|c|c|c|c|c|}
\hline Test & $\begin{array}{l}\text { Tests } \\
\text { (No.) }\end{array}$ & $\underset{(\%)}{\text { Correct }}$ & $\begin{array}{c}\text { False } \\
\text { Positive } \\
(\%)\end{array}$ & $\begin{array}{c}\text { False } \\
\text { Negative } \\
(\%)\end{array}$ & Reference \\
\hline $\begin{array}{l}\text { Hogben } \\
\text { Immunological } \\
\text { Preparation A }\end{array}$ & 1,436 & $\begin{array}{l}99 \cdot 4 \\
97 \cdot 0\end{array}$ & $\begin{array}{l}0 \\
2 \cdot 4\end{array}$ & $\begin{array}{l}0.6 \\
0.6\end{array}$ & $\left\{\begin{array}{l}\text { Hobson } \\
\text { (unpublished) }\end{array}\right.$ \\
\hline $\begin{array}{l}\text { Hogben } \\
\text { Immunological } \\
\text { Preparation B }\end{array}$ & 1,691 & $\begin{array}{l}99 \cdot 2 \\
97 \cdot 4\end{array}$ & $\begin{array}{l}0 \\
2 \cdot 3\end{array}$ & $\begin{array}{l}0 \cdot 8 \\
0 \cdot 3\end{array}$ & \}$^{\text {Barr, A. }}$ (in press) \\
\hline Total & 3,127 & & & & \\
\hline
\end{tabular}

The objection to the immunological tests at the moment is that the incorrect results are nearly all falsely positive. False-positive results are not obtained with the Hogben biological pregnancy test. At the moment our choice seems to be between an immunological test that will tell nearly 600 women each year that they are pregnant when they are not, and the biological test that will fail to detect the pregnancy of some 170 women.-I am, etc.,

Pregnancy Diagnosis Laboratory Department of Obstetrics and Gynaecology,
University of Edinburgh.

\section{REFERENCE}

1 Wide, L., and Gemzell, C. A., Acta endocr. (Kbh.), 1960, 35, 261

\section{Tests for Occult Blood}

SIR,--As Dr. R. G. Simpson pointed out in his letter (April 27, p. 1162) one of the most useful clinical sideroom procedures is stool-testing for occult blood. It is especially useful as a screening test in general practice. ${ }^{1}$ As Dr. Simpson indicated, the most popular and efficient test for occult blood is the Gregersen test. This modified benzidine test fell into disuse when benzidine was taken off the market because of the incidence of malignant bladder papilloma among those engaged in its manufacture. With the introduction of new methods of manufacture benzidine is now again available.

In addition to the many advantages described by Dr. Simpson, perhaps the greatest advantage of the Gregersen test over the "haematest" now most commonly used is that it is possible to detect with the Gregersen test, especially if the white-tile method is used, ${ }^{2}$ whether the blood is coming from higher up the bowel or from low down, as happens so often, for example, in haemorrhoids. With the Gregersen whitetile method blood coming from higher up the bowel produces a blue colour reaction, evenly and homogeneously distributed throughout the specimen; with local blood contamination the colour reaction is at once seen to be distributed streakily. For screening purposes it is extremely important to be able to make this distinction. With the haematest this distinction is not always possible, even if the usual precaution is taken of testing an inside portion of the stool.-I am, etc.,

Edinburgh 9.

S. LIPETZ.

REFERENCES

${ }^{1}$ Lipetz, S., Sklaroff, S. A., and Stein, L., Brit. med. J., 1955, 2, Practitioner, 1951, 166, 591.

Pregnancy in a Cornu of a Bicornuate Uterus

SIR,-Full-term pregnancy in a malformed uterus is uncommon. On March 29, 1962, a case was referred to us that from all clinical appearances and investiga- tions looked like an extrauterine pregnancy, and accurate diagnosis of pregnancy in a cornu of a bicornuate uterus was only made at laparotomy.

The patient, a Nigerian, aged about 22 years, and whose first pregnancy ended at 20 weeks, was now 32 weeks pregnant.

The clinical findings were as follows:

(1) A marked ridging of the uterus. The smaller part lay to the right and the larger part seemed fused with the left subcostal margin.

(2) What seemed to be two foetal heart-sounds were present-one was around the umbilicus and the second was more lateral, almost along the left inguinal ligament.

(3) The foetus was lying obliquely and was difficult to palpate.

(4) The cervix was long and firm. On bimanual examination one got the impression that one was feeling two distinct masses, a smaller rather fixed firm mass to the right and a softer more mobile mass to the left.

(5) Radiologist's (Dr. M. A. Ogakwu's) report was as follows: "The attitude of the foetus is bizarre. No definite uterine wall can be discerned surrounding the foetus. There may be some abnormality of dorsal spine.'

Except for the fact that Weiberg's and Shermin's sign were not present on $x$-ray, therefore, everything pointed to the case being one of extrauterine pregnancy.

The patient was detained and kept under constant observation. Her main complaint was a dull ache on the left flank. It was decided that if nothing unusual happened laparotomy would be performed at the 38 th week.

At laparotomy in the 38th week it was discovered that instead of a small uterus and a large extrauterine gestational sac a stocking-like shaped mass was felt. The larger and longer overstretched part lay to the left and contained the foetus, while the smaller and shorter firm part to the right looked like a 22-weeks pregnant uterus.

The baby was quickly removed through what looked like a poorly formed lower segment. It cried well and weighed $6 \mathrm{lb} .2 \mathrm{oz}$.

The uterus, on exploration, was made up of two compartments, with a communicating opening at the inferior end, the rest being divided by a muscular ridge, thick at the upper end, and tapering towards the lower end.

Post-partum haemorrhage, which we feared, was not as alarming as we had expected.

The patient was discharged 10 days later.- I am, etc.,

Enugu General Hospital,

B. V. О. Амові.

Nigeria.

\section{Dental Caries and Trace Elements}

SIR,-I would like to comment on your leading article entitled "Dental Caries and Trace Elements" (April 20, p. 1039). In this editorial you write that "Epidemiological studies in Oregon showed that the incidence of caries in both permanent and deciduous teeth was reduced by trace amounts of fluoride and vanadium and increased by selenium." The study mentioned in your article ${ }^{1}$ was conducted in the State of Wyoming and not in the State of Oregon. With regard to the trace element selenium, this investigation in Wyoming merely corroborated the findings of epidemiological studies conducted in Oregon some years ago by me and my associates which revealed, for the first time, that selenium appears to be a factor responsible for increasing the susceptibility to dental caries in children. $^{23}$

In a recent experiment with laboratory animals it was also shown that selenium significantly increased dental caries in white rats when administered during the period of tooth development and subsequently for a period of 120 days. $^{4}$ Furthermore, in recent years 